\title{
Anion Inhibition Profile of the $\beta$-Carbonic Anhydrase from the Opportunist Pathogenic Fungus Malassezia restricta Involved in Dandruff and Seborrheic Dermatitis
}

\author{
Sonia Del Prete ${ }^{1}$, Andrea Angeli ${ }^{2}$, Cynthia Ghobril ${ }^{3}$, Julien Hitce ${ }^{3}$, Cécile Clavaud ${ }^{3}$, \\ Xavier Marat ${ }^{3}$, Claudiu T. Supuran ${ }^{2, * \mathbb{D}}$ and Clemente Capasso ${ }^{1, * \mathbb{D}}$ \\ 1 Istituto di Bioscienze e Biorisorse, CNR, Via Pietro Castellino 111, I-80131 Napoli, Italy \\ 2 Sezione di Scienze Farmaceutiche e Nutraceutiche, Dipartimento Neurofarba, \\ Università degli Studi di Firenze, Via U. Schiff 6, I-50019 Sesto Fiorentino, Florence, Italy \\ 3 L'Oréal Research and Innovation, 93601 Aulnay-sous-Bois, France \\ * Correspondence: claudiu.supuran@unifi.it (C.T.S.); clemente.capasso@ibbr.cnr.it (C.C.)
}

Received: 24 June 2019; Accepted: 16 July 2019; Published: 18 July 2019

\begin{abstract}
Carbonic anhydrases (CAs, EC 4.2.1.1) are ubiquitous metalloenzymes, which catalyze the crucial physiological $\mathrm{CO}_{2}$ hydration/dehydration reaction $\left(\mathrm{CO}_{2}+\mathrm{H}_{2} \mathrm{O} \rightleftharpoons \mathrm{HCO}_{3}{ }^{-}+\mathrm{H}^{+}\right)$balancing the equilibrium between $\mathrm{CO}_{2}, \mathrm{H}_{2} \mathrm{CO}_{3}, \mathrm{HCO}_{3}{ }^{-}$and $\mathrm{CO}_{3}{ }^{2-}$. It has been demonstrated that their selective inhibition alters the equilibrium of the metabolites above affecting the biosynthesis and energy metabolism of the organism. In this context, our interest has been focalized on the fungus Malassezia restricta, which may trigger dandruff and seborrheic dermatitis altering the complex bacterial and fungal equilibrium of the human scalp. We investigated a rather large number of inorganic metal-complexing anions (a well-known class of CA inhibitors) for their interaction with the $\beta$-CA (MreCA) encoded by the $M$. restricta genome. The results were compared with those obtained for the two human $\alpha$-CA isoforms (hCAI and hCAII) and the $\beta$-CA from Malassezia globosa. The most effective MreCA inhibitors were diethyldithiocarbamate, sulfamide, phenyl arsenic acid, stannate, tellurate, tetraborate, selenocyanate, trithiocarbonate, and bicarbonate. The different $\mathrm{K}_{\mathrm{I}}$ values obtained for the four proteins investigated might be attributed to the architectural features of their catalytic site. The anion inhibition profile is essential for better understanding the inhibition/catalytic mechanisms of these enzymes and for designing novel types of inhibitors, which may have clinical applications for the management of dandruff and seborrheic dermatitis.
\end{abstract}

Keywords: carbonic anhydrases; metalloenzymes; anions; CA inhibitors; Malassezia restricta; Malassezia globosa; dandruff; seborrheic dermatitis

\section{Introduction}

In recent years, the pharmaceutical industry has focused its attention on inorganic drugs in addition to organic compounds [1,2]. This interest has been determined primarily because inorganic compounds are efficiently delivered in the body, in part because they are small molecules/ions, or they exploit oxidation and ligand substitution reactions [1,2]. Some of the well-known inorganic drugs incorporate metal ions, which are used in a variety of human disease treatments, such as silver sulphadiazine (antibacterial); auranofin (antiarthritic); sodium bromide (sedative); mercurochrome (antiseptic); lithium carbonate (anti-depressive); bismuth derivatives (anti-acid); cisplatin and carboplatin (anticancer); and zinc pyrithione and selenium sulfide (anti-dandruff agents) [3-6]. They are used in modern medicine to control cancer, infections, diabetes, neurological and cardiovascular 
problems, ulcers, and anti-inflammatory processes [3]. These small inorganic molecules can bind: (i) DNA to influence the protein expression level; (ii) membrane lipids for altering the integrity of the membrane; or (iii) proteins, in order to inhibit their functions [7]. For example, silver(I) ions and most silver compounds are toxic for bacteria, algae, and fungi in vitro [8]. The antibacterial action of the silver ions is due to their ability to irreversibly damage critical enzymes, which are localized in the cell membranes of pathogens [8,9]. In this context, recently small molecules belonging to anions, such as inorganic metal-complexing anions, have been extensively investigated as inhibitors of bacterial, fungal and protozoan metalloenzymes, such as carbonic anhydrases (CAs, EC 4.2.1.1) [10-13]. CAs are brand-named into eight genetically distinct families (or classes): $\alpha, \beta, \gamma, \delta, \zeta, \eta, \theta$, and ८ [14-19]. Since CAs catalyze the crucial physiological $\mathrm{CO}_{2}$ hydration/dehydration reaction $\left(\mathrm{CO}_{2}+\mathrm{H}_{2} \mathrm{O} \rightleftharpoons\right.$ $\left.\mathrm{HCO}_{3}{ }^{-}+\mathrm{H}^{+}\right)[14,18,20-25]$, balancing the equilibrium between dissolved inorganic carbon dioxide $\left(\mathrm{CO}_{2}\right)$, carbonic acid $\left(\mathrm{H}_{2} \mathrm{CO}_{3}\right)$, bicarbonate $\left(\mathrm{HCO}_{3}{ }^{-}\right)$and carbonate $\left(\mathrm{CO}_{3}{ }^{2-}\right)$ [26-29], their selective inhibition alters the equilibrium of the aforementioned metabolites affecting the biosynthesis and energy metabolism of the organism [30]. The metal-complexing anions, among the several classes of CA inhibitors (CAIs) (e.g., sulfonamides and their isosteres, dithiocarbamates, xanthates, phenols, polyamines, thioxocoumarins, sulfocoyumarins, and coumarins), bind the $\mathrm{Zn}(\mathrm{II})$ ion of the enzyme either in a tetrahedral geometry or as trigonal-bipyramidal adducts of the metal ion [12]. CAs are abundant in fungi and yeasts and have a crucial role in $\mathrm{CO}_{2}$-sensing in fungi and the regulation of their sexual development and virulence [12]. Generally, fungal genome encodes for one $\beta$-CA, even if multiple copies of $\beta$-and $\alpha$-CAs were reported for some fungi [12]. Fascinating is the fact that fungi belonging to the genus Malassezia are involved in dandruff and seborrheic dermatitis physiopathology [31]. For example, the $\beta$-CA (MgCA) encoded by the genome of Malassezia globosa represent an attractive druggable target since the main CA inhibitors (CAIs) can affect the in vivo and in animal model growth of the microorganism. Recently, an extensive study concerning the inhibition profile of MgCA has been reported using CAIs, such as sulfonamides, anions, a series of 6-substituted benzoxaboroles, monothiocarbamates, dithiocarbamates, famotidine, natural polyphenols, and phenols. The results identified efficient and selective inhibitors [32-38]. Recently, it has been demonstrated that Malassezia restricta represents the larger proportion of Malassezia sp. on the scalp in various populations and may also trigger dandruff and seborrheic dermatitis, in conjunction with the complex bacterial and fungal equilibrium of the human scalp [39-42]. The $\beta$-CA encoded by the genome of $M$. restricta (MreCA) is a 230 amino acid residues protein, which showed high catalytic activity for the hydration of $\mathrm{CO}_{2}$ to bicarbonate and protons, with a $\mathrm{k}_{\text {cat }}$ of $1.06 \times 10^{6} \mathrm{~s}^{-1}$ and $\mathrm{k}_{\text {cat }} / \mathrm{K}_{\mathrm{M}}$ of $1.07 \times 10^{8} \mathrm{M}^{-1} \mathrm{~s}^{-1}$ that is also sensitive to inhibition by the sulfonamide acetazolamide [31]. In the present paper, a range of inorganic/organic anions and other small molecules known as CAIs are investigated for their interaction with MreCA. The results are compared with those reported for the two human $\alpha$-CA isoforms (hCA I and hCA II) and the $\beta$-CA from Malassezia globosa in order to better understand the inhibition/catalytic mechanisms of these enzymes fundamental for many physiologic processes, and for designing novel types of inhibitors, which may have clinical applications for the management of dandruff and seborrheic dermatitis. Here, we show that MreCA exhibits a unique anion inhibition profile.

\section{Results and Discussion}

CAs have a crucial role in fungal biology since they sustain the bicarbonate-dependent carboxylation reactions, are necessary for the sexual reproduction in basidiomycetes and filamentous ascomycetes, and, are involved in $\mathrm{CO}_{2}$ sensing by producing the bicarbonate for the activation of adenylyl cyclase (cAMP), which regulates the fungal capsule biosynthesis or filamentation [43-45]. Thus, the study of the $\beta$-CA from $M$. restricta will be fundamental for a better comprehension of the biological functions of these enzymes, which can interfere with the life cycle of the fungus. In the present study, the recombinant $\beta$-CA (MreCA) encoded in the genome of the fungus M. restricta was prepared with a tail of six histidines at the C-terminus as reported previously [31]. The purified 
recombinant MreCA was detected at the molecular weight of about $26.0 \mathrm{kDa}$, which is the molecular mass of the fusion protein (His-tag + MreCA) (Figure 1).

STD 1

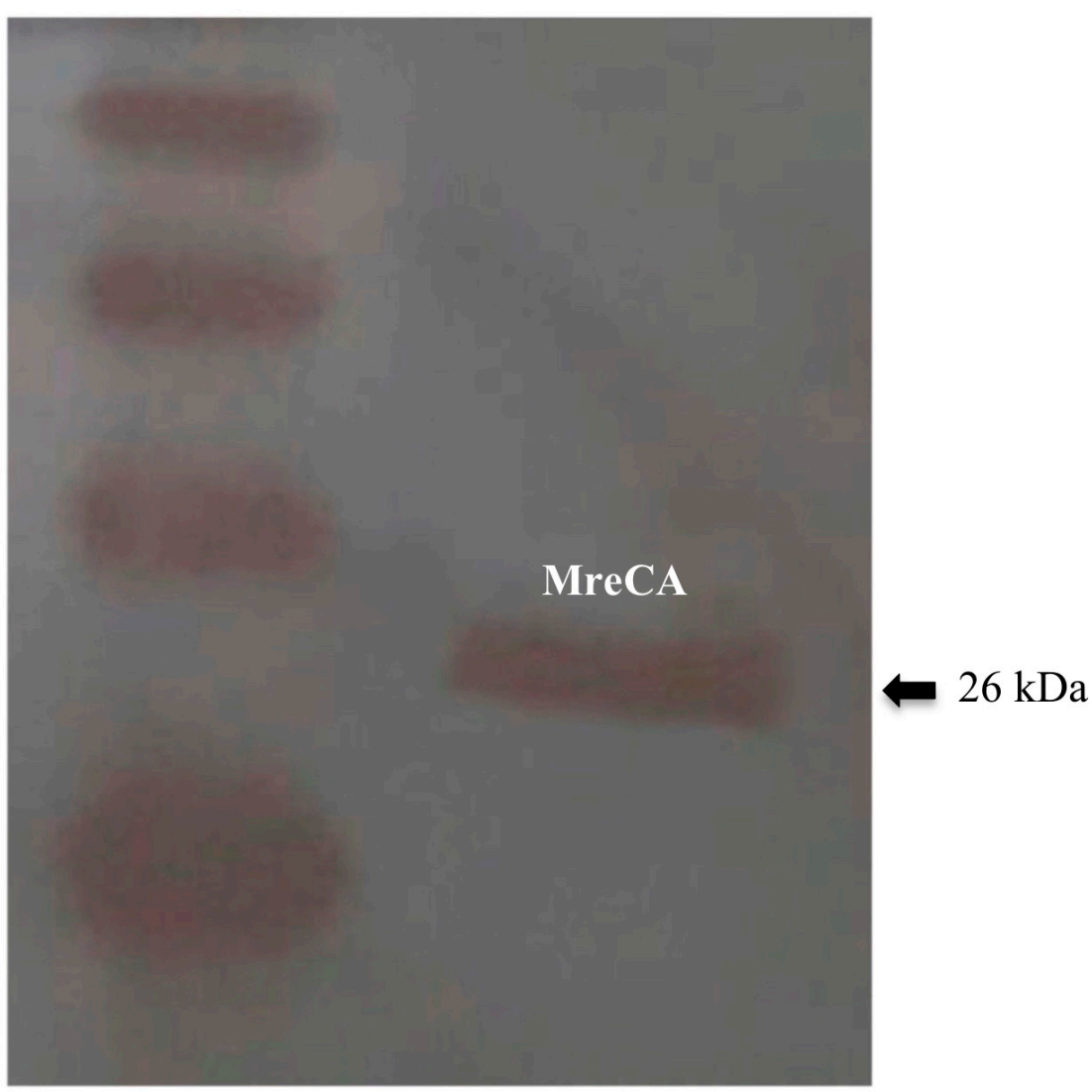

Figure 1. Western blot performed on the purified recombinant MreCA. Legend: Lane Std, MagicMark XP Western Protein Standard, Molecular Weight (M.W.) starting from the top: $50 \mathrm{kDa}, 40 \mathrm{kDa}, 30 \mathrm{kDa}$, and $20 \mathrm{kDa}$, each of which contains an IgG binding site; lane 1, purified MreCA. Bands were identified using the anti-His-Tag antibody.

Additionally, the stopped-flow technique confirmed that the present enzyme showed a high conversion of $\mathrm{CO}_{2}$ molecules to bicarbonate per second $\left(\mathrm{k}_{\mathrm{cat}}=1.06 \times 106 \mathrm{~s}^{-1}\right)$ and was efficiently inhibited by the classical sulfonamide inhibitor acetazolamide ( $\mathrm{K}_{\mathrm{I}}$ of $\left.50.7 \mathrm{nM}\right)$ [31]. Intriguingly, MreCA and its homologous enzyme (MgCA) from $M$. globosa are phylogenetically grouped with the $\beta-\mathrm{CA}$ encoded by the genome of Ustilago maydis, a pathogenic fungus responsible for the plant disease known as corn smut [46].

The MreCA amino acid sequence was aligned with that of the $\beta$-CA (acronym UmaCA) from $U$. maydis (Figure 1). The two sequences ( $\mathrm{MreCA}=230$ aa and $\mathrm{MgCA}=281$ aa) showed that the residues involved in the $\mathrm{Zn}$ (II) coordination are all conserved similar to the other $\beta$-CAs described in the literature (see Figure 2). Indeed, 100 identical amino acid residues and 138 residues with similar chemical properties (positive residues) have been detected in the sequence analysis of their primary structures (Figure 1). Thus, the identification of inhibitors that could interfere with the life cycle of $M$. restricta might constitute a unique strategy for fighting dandruff and seborrheic dermatitis. Moreover, the discovery of novel molecules targeting and inhibiting the fungal $\beta$-CA might offer the possibility to face out the smut of the maize caused by $U$. maydis. 


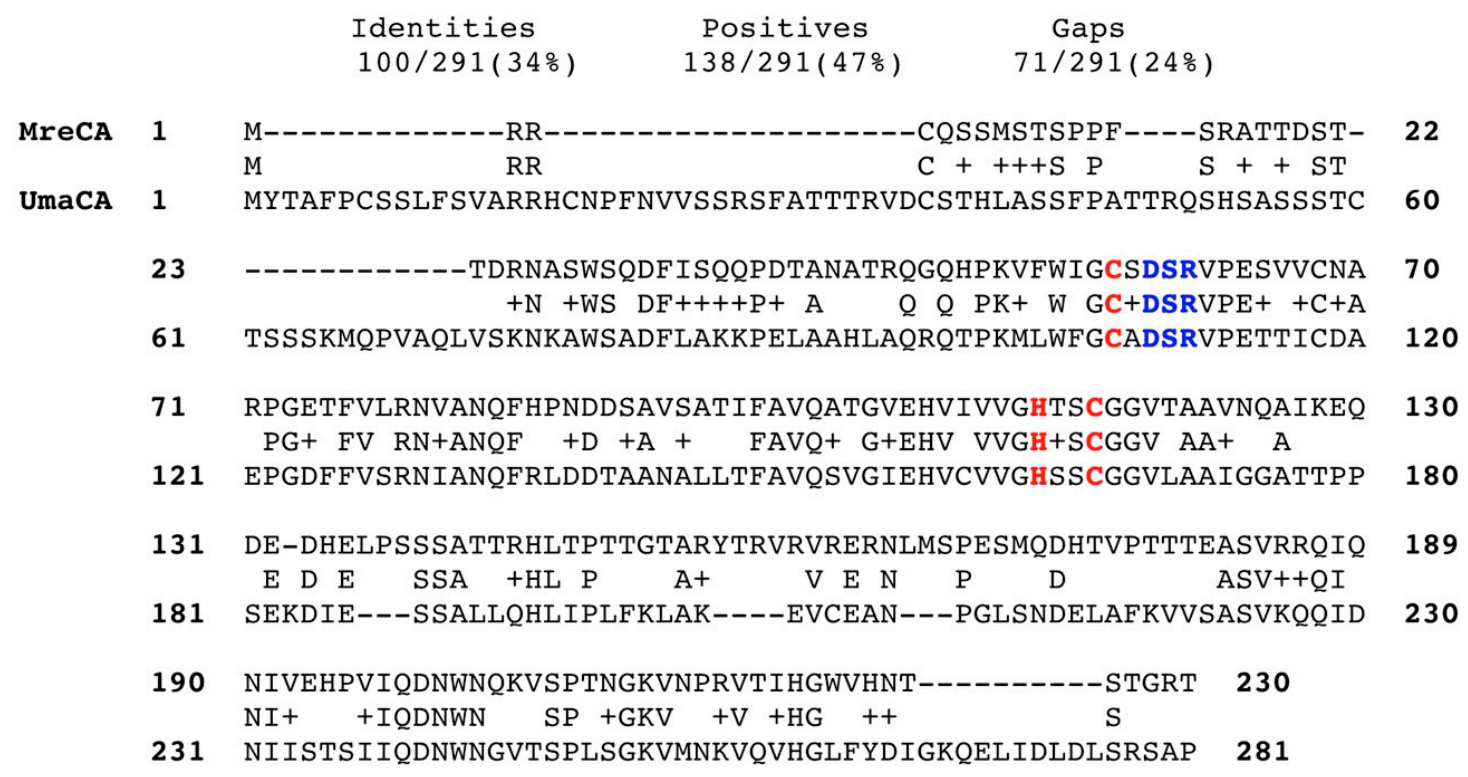

Figure 2. Sequence alignment of the selected $\beta$-CAs (MreCA and UmaCA). Zinc ligands are indicated in red; amino acids involved in the enzyme catalytic cycle are indicated in blue. The alignment was performed with the program Blast Global alignment. Legend: MreCA, Malassezia restricta $\beta$-CA; UmaCA, Ustilago maydis $\beta$-CA; + symbol, indicates the residues with the same biochemical properties; symbol, represents the gaps between the amino acid residues.

In this context, we investigated a rather large number of inorganic metal-complexing anions for their interaction with MreCA. The inorganic anions represent a well-known class of CA inhibitors (CAIs), due to their affinity for metal ions in solution or when bound within metalloenzyme active sites [47]. The anion inhibition profile of MreCA was compared with those obtained for the human $\alpha$-CAs (hCA I and hCA II) and the other fungal $\beta-\mathrm{CA}(\mathrm{MgCA})$, which have been previously investigated [33]. The results are shown in Table 1 and the following should be noted:

(i) Anions, which generally complex many cations, including $\mathrm{Zn}(\mathrm{II})$, such as fluoride, chloride, bromide, cyanate, thiocyanate, cyanide, nitrite, carbonate, bisulfite, sulfate, hydrogen sulfate, pyrophosphate, divanadate, perrhenate, peroxydisulfate, iminodisulfite, and fluorosulfonate, did not show any inhibitory action against MreCA $\left(\mathrm{K}_{\mathrm{I}}>50 \mathrm{mM}\right)$. It is interesting to note that MreCA has a very intriguingly inhibition pattern versus these anions when compared with its ortholog $\mathrm{MgCA}$, or the two human isoforms (hCA I and hCA II), MrCA being less or not inhibited by most of the anions tested. The enzyme from $M$. globosa showed a $\mathrm{K}_{\mathrm{I}}$ in the range of $4.06-21.4 \mathrm{mM}$ for most of these inhibitors, apart from carbonate, bisulfite, and peroxydisulfate. Indeed, the two human isoforms belonging to the $\alpha$-CA class were well inhibited by the "metal ion poisons", such as cyanide and azide. The behavior of MreCA is somewhat difficult to explain observing the different inhibition profile compared to MgCA, hCA I, and hCA II. However, it fortifies the thesis that the synthesis of new drugs capable of interfering selectively with MreCA and MgCA activity can avoid the inhibition of the human CAs ( $\alpha$-class enzymes), leading to the inactivation of the CAs encoded by the scalp microbes necessary for the integrity of the human skin.

(ii) Simple and complex anions investigated here, including iodide, nitrate, sulfamic acid, phenylboronic acid, perchlorate, osmate, perruthenate, esafluorofosfato, and trifalate, showed an interesting inhibition profile for MreCA, with $\mathrm{K}_{\mathrm{I}}$ ranging between 3.9 and $9.0 \mathrm{mM}$. Most of these anions showed a similar $\mathrm{K}_{\mathrm{I}}$ for the homologous enzyme $\mathrm{MgCA}$, with the exception of sulfamic acid and phenylboronic acid, which are very effective inhibitors of $\mathrm{MgCA}$, with $\mathrm{K}_{\mathrm{i}}$ of 0.083 and $0.089 \mathrm{mM}$, respectively. Interesting, the human isoforms (hCAI and hCAII) are not well inhibited by phenyl boronic acid. 
(iii) The most effective MreCA inhibitors identified in this study were bicarbonate, sulfamide, phenyl arsenic acid, stannate, tellurate, tetraborate, selenocyanate, trithiocarbonate, and diethyldithiocarbamate $\left(\mathrm{K}_{\mathrm{I}}\right.$ of $\left.0.075-0.86 \mathrm{mM}\right)$. These small molecules/anions are in fact well known to effectively inhibit many CAs belonging to all genetic families, as well as the two human isoforms (hCA I and hCA II).

Table 1. Inhibition constants of anionic inhibitors against the $\alpha$-CAs isoform (hCA I and hCA II) and the $\beta$-CAs from M. globosa and M. restricta (MgCA and MreCA) for the $\mathrm{CO}_{2}$ hydration reaction, at $20^{\circ} \mathrm{C}$ and $\mathrm{pH} 8.3$.

\begin{tabular}{|c|c|c|c|c|}
\hline \multicolumn{5}{|c|}{$\mathrm{K}_{\mathrm{I}}(\mathrm{mM}) *$} \\
\hline Inhibitor $\S$ & $\mathrm{hCA}^{\mathrm{a}}$ & hCA II $^{a}$ & $\mathrm{MgCA}^{\mathrm{a}}$ & MreCA $^{b}$ \\
\hline $\mathrm{F}^{-}$ & $>300$ & $>300$ & 7.13 & $>50$ \\
\hline $\mathrm{Cl}^{-}$ & 6 & 200 & 7.98 & $>50$ \\
\hline $\mathrm{Br}^{-}$ & 4 & 63 & 18.6 & $>50$ \\
\hline $\mathrm{I}^{-}$ & 0.3 & 26 & 8.73 & 8.6 \\
\hline $\mathrm{CNO}^{-}$ & 0.0007 & 0.03 & 6.81 & $>50$ \\
\hline $\mathrm{SCN}^{-}$ & 0.2 & 1.6 & 8.39 & $>50$ \\
\hline $\mathrm{CN}^{-}$ & 0.0005 & 0.02 & 7.19 & $>50$ \\
\hline $\mathrm{N}_{3}^{-}$ & 0.0012 & 1.51 & 45.2 & $>50$ \\
\hline $\mathrm{NO}_{2}{ }^{-}$ & 8.4 & 63 & 7.56 & $>50$ \\
\hline $\mathrm{NO}_{3}^{-}$ & 7 & 35 & 8.13 & 9 \\
\hline $\mathrm{HCO}_{3}^{-}$ & 12 & 85 & 0.59 & 0.86 \\
\hline $\mathrm{CO}_{3}^{2}$ & 15 & 73 & $>100$ & $>50$ \\
\hline $\mathrm{HSO}_{3}^{-}$ & 18 & 89 & $>100$ & $>50$ \\
\hline $\mathrm{SO}_{4}^{2-}$ & 63 & $>200$ & 19.5 & $>50$ \\
\hline $\mathrm{HS}^{-}$ & 0.0006 & 0.04 & 11.9 & $>50$ \\
\hline $\mathrm{H}_{2} \mathrm{NSO}_{2} \mathrm{NH}_{2}$ & 0.31 & 1.13 & 0.094 & 0.72 \\
\hline $\mathrm{NH}_{2} \mathrm{SO}_{3} \mathrm{H}$ & 0.021 & 0.39 & 0.083 & 7.7 \\
\hline $\mathrm{PhAsO}_{3} \mathrm{H}_{2}$ & 31.7 & 49.2 & 0.09 & 0.83 \\
\hline $\mathrm{PhB}(\mathrm{OH})_{2}$ & 58.6 & 23.1 & 0.089 & 8.7 \\
\hline $\mathrm{ClO}_{4}^{-}$ & $>200$ & $>200$ & $>100$ & 9.2 \\
\hline $\mathrm{SnO}_{3}{ }^{2-}$ & 0.57 & 0.83 & 5.07 & 0.56 \\
\hline $\mathrm{SeO}_{4}{ }^{2-}$ & 118 & 112 & 7.41 & 1.7 \\
\hline $\mathrm{TeO}_{4}{ }^{2-}$ & 0.66 & 0.92 & 5.75 & 0.56 \\
\hline $\mathrm{OsO}_{5}^{2-}$ & 0.92 & 0.95 & 6.16 & 8.5 \\
\hline $\mathrm{P}_{2} \mathrm{O}_{7}^{2-}$ & 25.77 & 48.5 & 6.03 & $>50$ \\
\hline $\mathrm{V}_{2} \mathrm{O}_{7}^{2-}$ & 0.54 & 0.57 & 6.89 & $>50$ \\
\hline $\mathrm{B}_{4} \mathrm{O}_{7}{ }^{2-}$ & 0.64 & 0.95 & 8.45 & 0.4 \\
\hline $\mathrm{ReO}_{4}^{-}$ & 0.11 & 0.75 & 16.7 & $>50$ \\
\hline $\mathrm{RuO}_{4}^{-}$ & 0.101 & 0.69 & 8.82 & 7.4 \\
\hline $\mathrm{S}_{2} \mathrm{O}_{8}{ }^{2-}$ & 0.107 & 0.084 & $>100$ & $>50$ \\
\hline $\mathrm{SeCN}^{-}$ & 0.085 & 0.086 & 1.73 & 0.65 \\
\hline $\mathrm{NH}\left(\mathrm{SO}_{3}\right)_{2}{ }^{2-}$ & 0.31 & 0.76 & 21.4 & $>50$ \\
\hline $\mathrm{FSO}_{3}^{-}$ & 0.79 & 0.46 & 4.06 & $>50$ \\
\hline $\mathrm{CS}_{3}{ }^{2-}$ & 0.0087 & 0.0088 & 1.77 & 0.92 \\
\hline $\mathrm{Et}_{2} \mathrm{NCS}_{2}{ }^{-}$ & 0.00079 & 0.0031 & 0.3 & 0.075 \\
\hline $\mathrm{PF}_{6}^{-}$ & $\mathrm{nt}$ & $\mathrm{nt}$ & 6.47 & 3.9 \\
\hline $\mathrm{CF}_{3} \mathrm{SO}_{3}^{-}$ & nt & nt & 2.28 & 4.5 \\
\hline
\end{tabular}

* Mean from three different assays, by a stopped flow technique (errors were in the range of $\pm 3-5 \%$ of the reported values); § As sodium salt, except sulfamide, phenylboronic acid and phenylarsonic acid; ${ }^{\text {a }}$ Data reported previously in Ref. [31]; ${ }^{\mathrm{b}}$ this work. 


\section{Materials and Methods}

\subsection{Cloning and Purification of MreCA}

The amino acid sequence of Malassezia restricta corresponding to a $\beta$-CA was back-translated into the nucleotide sequence and optimized for the codon usage to increase its expression in Escherichia coli cells. The synthetic $M$. restricta gene, as obtained from GeneArt Company (Milan, Italy) was cloned into the expression vector to obtain the pET100D-Topo/MreCA. Competent Escherichia coli BL21 (DE3) codon plus cells (Agilent) were transformed with pET100D-Topo/MreCA and induced with Isopropyl $\beta$-D-1-thiogalactopyranoside (IPTG). After growth, the cells were harvested and disrupted by sonication. The cellular extract was loaded and purified onto a His-select High-Flow (HF) Nickel affinity column. After the column, the resulting enzyme was $80 \%$ pure.

\subsection{Western Blotting}

MreCA was subjected to a $12 \%(w / v)$ SDS-PAGE, followed by electrophoretic transfer to a PVDF membrane with transfer buffer (25 mM Tris, $192 \mathrm{mM}$ glycine, 20\% methanol) using Trans-Plot SD Cell (Bio-Rad, Hercules, CA, USA). His-Tag Western blot was carried out using the Pierce Fast Western Blot Kit (Thermo Scientific, Waltham, MA, USA). Blotted membrane had been placed in the wash blot solution Fast Western 1 Wash Buffer to remove transfer buffer. Primary Antibody Working Dilution was added to the blot and incubated for $30 \mathrm{~min}$ at room temperature (RT) with shaking. Afterwards, the blot was removed from the primary antibody solution and incubated for 10 min with the Fast Western Optimised HRP Reagent Working Dilution. Subsequently, the membrane was washed two times in about $20 \mathrm{~mL}$ of Fast Western 1 Wash Buffer. Finally, the membrane was incubated with the detection reagent working solution and incubated for $1 \mathrm{~min}$ at room temperature and then developed with X-ray film.

\subsection{Determination of the Inhibition Constants}

An Applied Photophysics stopped-flow instrument was used for assaying the $\mathrm{CA}$ catalyzed $\mathrm{CO}_{2}$ hydration activity [48]. Bromothymol blue (at a concentration of $0.2 \mathrm{mM}$ ) was used as an indicator, working at the absorbance maximum of $557 \mathrm{~nm}$, with 10-20 mM TRIS (pH 8.3) as buffer and $20 \mathrm{mM}$ $\mathrm{Na}_{2} \mathrm{SO}_{4}$ for maintaining constant ionic strength (this anion is not inhibitory and has a $\mathrm{K}_{\mathrm{I}}>200 \mathrm{mM}$ against this enzyme), following the initial rates of the $\mathrm{CA}$-catalyzed $\mathrm{CO}_{2}$ hydration reaction for a period of 10-100 s. The $\mathrm{CO}_{2}$ concentrations ranged from 1.7 to $17 \mathrm{mM}$ for the determination of the kinetic parameters and inhibition constants. For each measurement, at least six traces of the initial $5-10 \%$ of the reaction were used for determining the initial velocity, working with 10 -fold decreasing inhibitor concentrations ranging between $1 \mathrm{nM}$ and 10-100 $\mu \mathrm{M}$ (depending on the inhibitor potency, but at least 5 points at different inhibitor concentrations were employed for determining the inhibition constants). The uncatalyzed rates were determined in the same manner and subtracted from the total observed rates. Stock solutions of inhibitor $(0.1 \mathrm{mM})$ were prepared in distilled-deionized water and dilutions up to $1 \mathrm{nM}$ were done thereafter with the assay buffer. Inhibitor and enzyme solutions were preincubated together for $15 \mathrm{~min}$ at room temperature before assay, in order to allow for the formation of the E-I complex. The inhibition constants were obtained by non-linear least-squares methods using the Cheng-Prusoff equation, and represent the mean from at least three different determinations. The human isoforms hCA I and II and the fungus MgCA were assayed in the same conditions as above, with 4-(2-hydroxyethyl)-1-piperazineethanesulfonic acid (HEPES) buffer and phenol red as an indicator [49]. All enzymes were recombinant and produced as described earlier in our laboratory [49-53].

\section{Conclusions}

Malassezia restricta is one of the micro-organisms involved in the disequilibrium between various commensals, such as M. globosa, Cutibacterium acnes (formerly named Propionibacterium acnes) and Staphylococcus sp., which contribute to dandruff and seborrheic dermatitis symptoms $[39,41,42,53]$. We 
have cloned, purified, and investigated the anion inhibition profile of the $\beta$-CA (MreCA) encoded by the $M$. restricta genome. Indeed, a full inhibition profile of MreCA, as well as the ortholog enzyme $\mathrm{MgCA}$, and the possible off-targets hCA I and hCA II, was carried out with the known CA inorganic metal-complexing anions. MreCA activity, diversely from its homologous $\mathrm{MgCA}$, is not readily inhibited by anions, which generally complex effectively cations (e.g., fluoride, chloride, bromide, cyanate, thiocyanate, cyanide). The most effective MreCA inhibitors were diethyldithiocarbamate, sulfamide, phenyl arsenic acid, stannate, tellurate, tetraborate, selenocyanate, trithiocarbonate, and bicarbonate. As described in the literature, the compounds investigated bind to the $\mathrm{Zn}$ (II) ion in the enzyme active site either by substituting the nucleophile (water molecule/hydroxide ion) as the fourth zinc ligand or by adding to the zinc coordination sphere to generate a trigonal bipyramidal geometry relative to the metal ion. The final result is a possible inactivation of the enzyme due to the degree of the structural distortion caused by the inhibitor. Thus, although CAs have a similar catalytic site, each biocatalyst has unusual architectural features, which must occur in the interaction between the protein and the anions investigated, explaining the differences in the degree of structural distortion and the different $\mathrm{K}_{\mathrm{I}}$ values obtained for the four proteins studied. In conclusion, the investigation of the anion inhibition profiles of the fungal CA enzymes represents a significant starting point for designing novel metal-based antifungal treatments, which need to be further investigated using structural analysis of MrCA

Author Contributions: Data curation, C.G., J.H., C.C. (Cécile Clavaud) and X.M.; Funding acquisition, C.C. (Cécile Clavaud) and X.M.; Investigation, S.D.P., A.A. and C.C. (Clemente Capasso); Supervision, C.T.S. and C.C. (Clemente Capasso); Writing—original draft, C.C. (Clemente Capasso); Writing—review \& editing, C.T.S. and C.C. (Clemente Capasso).

Funding: This research was entirely funded by L'Oréal Research \& Innovation.

Conflicts of Interest: The sponsors had no role in the design, execution, interpretation, or writing of the study. The authors declare no conflict of interest.

\section{References}

1. Alonso-de Castro, S.; Terenzi, A.; Gurruchaga-Pereda, J.; Salassa, L. Catalysis concepts in medicinal inorganic chemistry. Chemistry 2019, 25, 6651-6660. [CrossRef] [PubMed]

2. Mjos, K.D.; Orvig, C. Metallodrugs in medicinal inorganic chemistry. Chem. Rev. 2014, 114, 4540-4563. [CrossRef] [PubMed]

3. Gambino, D. Advances and current perspectives in medicinal inorganic chemistry. Curr. Med. Chem. 2010, 17, 3605. [CrossRef] [PubMed]

4. Reeder, N.L.; Kaplan, J.; Xu, J.; Youngquist, R.S.; Wallace, J.; Hu, P.; Juhlin, K.D.; Schwartz, J.R.; Grant, R.A.; Fieno, A.; et al. Zinc pyrithione inhibits yeast growth through copper influx and inactivation of iron-sulfur proteins. Antimicrob. Agents Chemother. 2011, 55, 5753-5760. [CrossRef] [PubMed]

5. Flesch, P. On the mode of action of selenium sulfide. J. Invest. Dermatol. 1953, 21, 233-235. [CrossRef] [PubMed]

6. Schmidt-Rose, T.; Braren, S.; Folster, H.; Hillemann, T.; Oltrogge, B.; Philipp, P.; Weets, G.; Fey, S. Efficacy of a piroctone olamine/climbazol shampoo in comparison with a zinc pyrithione shampoo in subjects with moderate to severe dandruff. Int. J. Cosmet. Sci. 2011, 33, 276-282. [CrossRef]

7. Haas, K.L.; Franz, K.J. Application of metal coordination chemistry to explore and manipulate cell biology. Chem. Rev. 2009, 109, 4921-4960. [CrossRef] [PubMed]

8. Tsang, K.K.; Kwong, E.W.; Woo, K.Y.; To, T.S.; Chung, J.W.; Wong, T.K. The anti-inflammatory and antibacterial action of nanocrystalline silver and manuka honey on the molecular alternation of diabetic foot ulcer: A comprehensive literature review. Evid. Based Complement. Alternat. Med. 2015, 2015, 218283. [CrossRef]

9. Dakal, T.C.; Kumar, A.; Majumdar, R.S.; Yadav, V. Mechanistic basis of antimicrobial actions of silver nanoparticles. Front. Microbiol. 2016, 7, 1831. [CrossRef]

10. Angeli, A.; Pinteala, M.; Maier, S.S.; Del Prete, S.; Capasso, C.; Simionescu, B.C.; Supuran, C.T. Inhibition of alpha-, beta-, gamma-, delta-, zeta- and eta-class carbonic anhydrases from bacteria, fungi, algae, diatoms and protozoans with famotidine. J. Enzyme Inhib. Med. Chem. 2019, 34, 644-650. [CrossRef] 
11. Carta, F.; Osman, S.M.; Vullo, D.; AlOthman, Z.; Del Prete, S.; Capasso, C.; Supuran, C.T. Poly(amidoamine) dendrimers show carbonic anhydrase inhibitory activity against alpha-, beta-, gamma- and eta-class enzymes. Bioorg. Med. Chem. 2015, 23, 6794-6798. [CrossRef] [PubMed]

12. Capasso, C.; Supuran, C.T. Bacterial, fungal and protozoan carbonic anhydrases as drug targets. Expert Opin. Ther. Targets 2015, 19, 1689-1704. [CrossRef] [PubMed]

13. Capasso, C.; Supuran, C.T. Anti-infective carbonic anhydrase inhibitors: A patent and literature review. Expert Opin. Ther. Pat. 2013, 23, 693-704. [CrossRef] [PubMed]

14. Annunziato, G.; Angeli, A.; D’Alba, F.; Bruno, A.; Pieroni, M.; Vullo, D.; De Luca, V.; Capasso, C.; Supuran, C.T.; Costantino, G. Discovery of new potential anti-infective compounds based on carbonic anhydrase inhibitors by rational target-focused repurposing approaches. ChemMedChem 2016, 11, 1904-1914. [CrossRef] [PubMed]

15. Ozensoy Guler, O.; Capasso, C.; Supuran, C.T. A magnificent enzyme superfamily: Carbonic anhydrases, their purification and characterization. J. Enzyme Inhib. Med. Chem. 2016, 31, 689-694. [CrossRef] [PubMed]

16. Del Prete, S.; Vullo, D.; De Luca, V.; Carginale, V.; Ferraroni, M.; Osman, S.M.; AlOthman, Z.; Supuran, C.T.; Capasso, C. Sulfonamide inhibition studies of the beta-carbonic anhydrase from the pathogenic bacterium vibrio cholerae. Bioorg. Med. Chem. 2016, 24, 1115-1120. [CrossRef] [PubMed]

17. Del Prete, S.; De Luca, V.; De Simone, G.; Supuran, C.T.; Capasso, C. Cloning, expression and purification of the complete domain of the eta-carbonic anhydrase from plasmodium falciparum. J. Enzyme Inhib. Med. Chem. 2016, 31, 54-59. [CrossRef] [PubMed]

18. Capasso, C.; Supuran, C.T. An overview of the carbonic anhydrases from two pathogens of the oral cavity: Streptococcus mutans and porphyromonas gingivalis. Curr. Top. Med. Chem. 2016, 16, 2359-2368. [CrossRef] [PubMed]

19. Jensen, E.L.; Clement, R.; Kosta, A.; Maberly, S.C.; Gontero, B. A new widespread subclass of carbonic anhydrase in marine phytoplankton. ISME J. 2019, 1, 1-13. [CrossRef] [PubMed]

20. Del Prete, S.; Vullo, D.; De Luca, V.; Carginale, V.; Osman, S.M.; AlOthman, Z.; Supuran, C.T.; Capasso, C. Cloning, expression, purification and sulfonamide inhibition profile of the complete domain of the eta-carbonic anhydrase from plasmodium falciparum. Bioorg. Med. Chem. Lett. 2016, 26, 4184-4190. [CrossRef] [PubMed]

21. Del Prete, S.; Vullo, D.; De Luca, V.; Carginale, V.; di Fonzo, P.; Osman, S.M.; AlOthman, Z.; Supuran, C.T.; Capasso, C. Anion inhibition profiles of the complete domain of the eta-carbonic anhydrase from plasmodium falciparum. Bioorg. Med. Chem. 2016, 24, 4410-4414. [CrossRef]

22. Del Prete, S.; Vullo, D.; De Luca, V.; Carginale, V.; di Fonzo, P.; Osman, S.M.; AlOthman, Z.; Supuran, C.T.; Capasso, C. Anion inhibition profiles of alpha-, beta- and gamma-carbonic anhydrases from the pathogenic bacterium vibrio cholerae. Bioorg. Med. Chem. 2016, 24, 3413-3417. [CrossRef]

23. Abdel Gawad, N.M.; Amin, N.H.; Elsaadi, M.T.; Mohamed, F.M.; Angeli, A.; De Luca, V.; Capasso, C.; Supuran, C.T. Synthesis of 4-(thiazol-2-ylamino)-benzenesulfonamides with carbonic anhydrase i, ii and ix inhibitory activity and cytotoxic effects against breast cancer cell lines. Bioorg. Med. Chem. 2016, 24, 3043-3051. [CrossRef]

24. Del Prete, S.; Vullo, D.; De Luca, V.; Carginale, V.; Osman, S.M.; AlOthman, Z.; Supuran, C.T.; Capasso, C. Comparison of the sulfonamide inhibition profiles of the alpha-, beta- and gamma-carbonic anhydrases from the pathogenic bacterium vibrio cholerae. Bioorg. Med. Chem. Lett. 2016, 26, 1941-1946. [CrossRef]

25. Smith, K.S.; Ferry, J.G. Prokaryotic carbonic anhydrases. FEMS Microbiol. Rev. 2000, 24, 335-366. [CrossRef]

26. Maeda, S.; Price, G.D.; Badger, M.R.; Enomoto, C.; Omata, T. Bicarbonate binding activity of the cmpa protein of the cyanobacterium synechococcus sp. Strain pcc 7942 involved in active transport of bicarbonate. J. Biol. Chem. 2000, 275, 20551-20555. [CrossRef]

27. Joseph, P.; Ouahrani-Bettache, S.; Montero, J.L.; Nishimori, I.; Minakuchi, T.; Vullo, D.; Scozzafava, A.; Winum, J.Y.; Kohler, S.; Supuran, C.T. A new beta-carbonic anhydrase from brucella suis, its cloning, characterization, and inhibition with sulfonamides and sulfamates, leading to impaired pathogen growth. Bioorg. Med. Chem. 2011, 19, 1172-1178. [CrossRef]

28. Joseph, P.; Turtaut, F.; Ouahrani-Bettache, S.; Montero, J.L.; Nishimori, I.; Minakuchi, T.; Vullo, D.; Scozzafava, A.; Kohler, S.; Winum, J.Y.; et al. Cloning, characterization, and inhibition studies of a beta-carbonic anhydrase from brucella suis. J. Med. Chem. 2010, 53, 2277-2285. [CrossRef]

29. Murima, P.; McKinney, J.D.; Pethe, K. Targeting bacterial central metabolism for drug development. Chem. Biol. 2014, 21, 1423-1432. [CrossRef] 
30. Del Prete, S.; Vullo, D.; Ghobril, C.; Hitce, J.; Clavaud, C.; Marat, X.; Capasso, C.; Supuran, C.T. Cloning, purification, and characterization of a beta-carbonic anhydrase from malassezia restricta, an opportunistic pathogen involved in dandruff and seborrheic dermatitis. Int. J. Mol. Sci. 2019, 20, 2447. [CrossRef]

31. Nocentini, A.; Cadoni, R.; Del Prete, S.; Capasso, C.; Dumy, P.; Gratteri, P.; Supuran, C.T.; Winum, J.-Y. Benzoxaboroles as efficient inhibitors of the beta-carbonic anhydrases from pathogenic fungi: Activity and modeling study. ACS Med. Chem. Lett. 2017, 8, 1194-1198. [CrossRef]

32. Del Prete, S.; Vullo, D.; Osman, S.M.; AlOthman, Z.; Capasso, C.; Supuran, C.T. Anion inhibition studies of the dandruff-producing fungus malassezia globosa beta-carbonic anhydrase mgca. Bioorg. Med. Chem. Lett. 2015, 25, 5194-5198. [CrossRef]

33. Vullo, D.; Del Prete, S.; Nocentini, A.; Osman, S.M.; AlOthman, Z.; Capasso, C.; Bozdag, M.; Carta, F.; Gratteri, P.; Supuran, C.T. Dithiocarbamates effectively inhibit the beta-carbonic anhydrase from the dandruff-producing fungus malassezia globosa. Bioorg. Med. Chem. 2017, 25, 1260-1265. [CrossRef]

34. Nocentini, A.; Vullo, D.; Del Prete, S.; Osman, S.M.; Alasmary, F.A.S.; AlOthman, Z.; Capasso, C.; Carta, F.; Gratteri, P.; Supuran, C.T. Inhibition of the beta-carbonic anhydrase from the dandruff-producing fungus malassezia globosa with monothiocarbamates. J. Enzyme Inhib. Med. Chem. 2017, 32, 1064-1070. [CrossRef]

35. Nocentini, A.; Bua, S.; Del Prete, S.; Heravi, Y.E.; Saboury, A.A.; Karioti, A.; Bilia, A.R.; Capasso, C.; Gratteri, P.; Supuran, C.T. Natural polyphenols selectively inhibit beta-carbonic anhydrase from the dandruff-producing fungus malassezia globosa: Activity and modeling studies. ChemMedChem 2018, 13, 816-823. [CrossRef]

36. Entezari Heravi, Y.; Bua, S.; Nocentini, A.; Del Prete, S.; Saboury, A.A.; Sereshti, H.; Capasso, C.; Gratteri, P.; Supuran, C.T. Inhibition of malassezia globosa carbonic anhydrase with phenols. Bioorg. Med. Chem. 2017, 25, 2577-2582. [CrossRef]

37. Clavaud, C.; Jourdain, R.; Bar-Hen, A.; Tichit, M.; Bouchier, C.; Pouradier, F.; El Rawadi, C.; Guillot, J.; Menard-Szczebara, F.; Breton, L.; et al. Dandruff is associated with disequilibrium in the proportion of the major bacterial and fungal populations colonizing the scalp. PLoS ONE 2013, 8, e58203. [CrossRef]

38. Park, T.; Kim, H.-J.; Myeong, N.R.; Lee, H.G.; Kwack, I.; Lee, J.; Kim, B.J.; Sul, W.J.; An, S. Collapse of human scalp microbiome network in dandruff and seborrhoeic dermatitis. Exp. Dermatol. 2017, 26, 835-838. [CrossRef]

39. Stalhberger, T.; Simenel, C.; Clavaud, C.; Eijsink, V.G.H.; Jourdain, R.; Delepierre, M.; Latge, J.-P.; Breton, L.; Fontaine, T. Chemical organization of the cell wall polysaccharide core of malassezia restricta. J. Biol. Chem. 2014, 289, 12647-12656. [CrossRef]

40. Morand, S.C.; Bertignac, M.; Iltis, A.; Kolder, I.C.R.M.; Pirovano, W.; Jourdain, R.; Clavaud, C. Complete genome sequence of malassezia restricta cbs 7877, an opportunist pathogen involved in dandruff and seborrheic dermatitis. Microbiol. Resour. Announc. 2019, 8, e01543-18. [CrossRef]

41. Elleuche, S.; Poggeler, S. Carbonic anhydrases in fungi. Microbiology 2010, 156, 23-29. [CrossRef]

42. Han, K.-H.; Chun, Y.-H.; Figueiredo, B.d.C.P.; Soriani, F.M.; Savoldi, M.; Almeida, A.; Rodrigues, F.; Cairns, C.T.; Bignell, E.; Tobal, J.M.; et al. The conserved and divergent roles of carbonic anhydrases in the filamentous fungi aspergillus fumigatus and aspergillus nidulans. Mol. Microbiol. 2010, 75, 1372-1388. [CrossRef]

43. Xu, J.; Saunders, C.W.; Hu, P.; Grant, R.A.; Boekhout, T.; Kuramae, E.E.; Kronstad, J.W.; Deangelis, Y.M.; Reeder, N.L.; Johnstone, K.R.; et al. Dandruff-associated malassezia genomes reveal convergent and divergent virulence traits shared with plant and human fungal pathogens. Proc. Natl. Acad. Sci. USA 2007, 104, 18730-18735. [CrossRef]

44. Supuran, C.T. How many carbonic anhydrase inhibition mechanisms exist? J. Enzyme Inhib. Med. Chem. 2016, 31, 345-360. [CrossRef]

45. Mass, T.; Giuffre, A.J.; Sun, C.-Y.; Stifler, C.A.; Frazier, M.J.; Neder, M.; Tamura, N.; Stan, C.V.; Marcus, M.A.; Gilbert, P.U.P.A. Amorphous calcium carbonate particles form coral skeletons. Proc. Natl. Acad. Sci. USA 2017, 114, E7670-E7678. [CrossRef]

46. Khalifah, R.G. The carbon dioxide hydration activity of carbonic anhydrase. I. Stop-flow kinetic studies on the native human isoenzymes b and c. J. Biol. Chem. 1971, 246, 2561-2573.

47. Carta, F.; Scozzafava, A.; Supuran, C.T. Sulfonamides: A patent review (2008-2012). Expert Opin. Ther. Pat. 2012, 22, 747-758. [CrossRef] 
48. Pastorekova, S.; Casini, A.; Scozzafava, A.; Vullo, D.; Pastorek, J.; Supuran, C.T. Carbonic anhydrase inhibitors: The first selective, membrane-impermeant inhibitors targeting the tumor-associated isozyme ix. Bioorg. Med. Chem. Lett. 2004, 14, 869-873. [CrossRef]

49. Scozzafava, A.; Carta, F.; Supuran, C.T. Secondary and tertiary sulfonamides: A patent review (2008-2012). Expert Opin. Ther. Pat. 2013, 23, 203-213. [CrossRef]

50. Supuran, C.T. Carbonic anhydrase inhibitors as emerging drugs for the treatment of obesity. Expert Opin. Emerg. Drugs 2012, 17, 11-15. [CrossRef]

51. Schlicker, C.; Hall, R.A.; Vullo, D.; Middelhaufe, S.; Gertz, M.; Supuran, C.T.; Muhlschlegel, F.A.; Steegborn, C. Structure and inhibition of the co2-sensing carbonic anhydrase can2 from the pathogenic fungus cryptococcus neoformans. J. Mol. Biol. 2009, 385, 1207-1220. [CrossRef]

52. Innocenti, A.; Muhlschlegel, F.A.; Hall, R.A.; Steegborn, C.; Scozzafava, A.; Supuran, C.T. Carbonic anhydrase inhibitors: Inhibition of the beta-class enzymes from the fungal pathogens candida albicans and cryptococcus neoformans with simple anions. Bioorg. Med. Chem. Lett. 2008, 18, 5066-5070. [CrossRef]

53. Wang, L.; Clavaud, C.; Bar-Hen, A.; Cui, M.; Gao, J.; Liu, Y.; Liu, C.; Shibagaki, N.; Gueniche, A.; Jourdain, R.; et al. Characterization of the major bacterial-fungal populations colonizing dandruff scalps in Shanghai, China, shows microbial disequilibrium. Exp. Dermatol. 2015, 24, 398-400. [CrossRef]

(C) 2019 by the authors. Licensee MDPI, Basel, Switzerland. This article is an open access article distributed under the terms and conditions of the Creative Commons Attribution (CC BY) license (http://creativecommons.org/licenses/by/4.0/). 